come of the adoption by the Commission in 1957 of the recommendation of a Specialist Committee in Economics. Its 1,377 entries are confined almost entirely to publications dealing specifically with African regions or countries, but it has proved unusually difficult to draw the line between economics and anthropology and between political economy and politics. The entries are arranged alphabetically by author, first, geographically, under Africa General ; Belgian Congo ; French Republic and Community ; Portuguese Africa; Spanish Africa; British Africa; Ghana, Central Africa; and South Africa. Within these sections the entries are classified by subject and there is an author index. Entries and annotations are in English and French.

\section{Museum and Art Gallery, Durban}

THE annual report of the Durban Museum and Art Gallery for the municipal year 1958-59 records that curatorial work has mainly centred on the new Marine Hall (pp. 19. Durban : Durban Museum and Art Gallery, 1959). The exhibits of sharks, rays, skates, turtle and Cape sealion have been installed and work on a large exhibit of the major game fishes of the Natal coast is nearly complete. After many experiments plastic has been used to good effect in these recent marine displays. The output of research work on the collections by the staff remains at a high level. Display and storage accommodation at the Old House Museum (which serves as a branch Folk Museum) is now so limited that serious consideration must be given in the relatively near future to the provision of an additional building, either as a separate entity in the grounds or as a wing of the Old House.

\section{Field Studies Council}

Measured by the quality of the courses conducted, the number of students attending the centres, and the financial outcome of the year's operation, the report of the Field Studies Council for 1958-59 is again one of continued progress. ( $\mathrm{Pp} .34+4$ plates. London : Field Studies Council, 1960.) Over the past nine years the total number of bookings at the Centres has risen from 3,483 to 7,903 . Of these, more than half were students of biological subjects, and more than a quarter of geographical and geological subjects. A surprising number of those attending took courses in art and archæology. Well over half the students attending were from grammar schools but, regrettably, the numbers attending from secondary modern schools remained very small; this is a matter to which education authorities should be asked to pay eloser attention. Because of the establishment of a new centre at Slapton Ley, the Ministry of Education generously agreed not to carry out its declared intention progressively to reduce the $£ 5,000$ annual grant. The reduction will now begin next year and will not lead to much embarrassment. Further information concerning the work of the Council can be obtained from Mrs. F. H. C. Butler, Ravensmead, Keston, Kent.

\section{Reference Books on Mineralogy in the U.S.S.R.}

Tres Academy of Sciences of the U.S.S.R. is planning to publish in 1959-65 a collection of reference books on mineralogy. The subjects covered by the projected volumes are as follows: Vol. 1, introduction, native elements, intermetallic compounds, arsenides and antimonides, sulphides; Vol. 2, haloids ; Vol. 3, silicates (part 1); Vol. 4, silicates (part 2); Vol. 5, niobates and tantalates, carbonates, nitrates, borates, sulphates ; Vol. 6, phosphates, arsenates and vanadates, tungstates, molybdates, etc.; Vol. 7, diagrams illustrating phase equilibria important in mineralogy. The size of each volume is estimated to be 500 pages and the price 38-40 roubles. This collection of reference books will be prepared under the auspices of the Institute of the Geology of Ore Deposits, Petrography, Mineralogy and Geochemistry, and of the Mineralogical Museum of the Academy of Sciences.

\section{Scientific Bibliography of Latin America}

THE Conference of Latin American Scientific Experts convened by the United Nations Educational, Scientific and Cultural Organization at Montevideo in September 1948 requested the preparation of a Latin American biobibliography (Unesco: Centro de Cooperacion Cientifica para America Latina. Scientific Institutions and Scientists in Latin-America. Paraguay (ler Volumen). Pp. ii +93 . Chile $\left(2^{\circ}\right.$ Volumen). Pp. ii +40 . Montevideo : Unesco, Centro de Cooperacion Cientifica para America Latina, 1959). The preparation of this was undertaken by Unesco's Field Science Co-operation Office for Latin America in collaboration with IberoAmerican organizations, and Vol. 1 contains a first list of Paraguayan scientists and scientific organizations. Scientists are listed alphabetically, with particulars of their qualifications and experience and publications. Vol. 2 gives similar data for institutions and scientists in Chile.

\section{lonosphere over Belgium during the International Geophysical Year}

THE Royal Meteorological Institute of Belgium has been publishing monthly bulletins of the ionospheric observations taken at the station of Dourbres (lat. $50^{\circ} 06^{\prime} \mathrm{N}$., long. $04^{\circ} 36^{\prime} \mathrm{E}$.) during the International Geophysical Year (Royal Meteorological Institute of Belgium, Avenue Circulaire, 3, Uccle, Brussels, 18). An automatic ionosonde of the U.S. National Bureau of Standards type $C-2$ was used; this sweeps over the range of frequencies from 1 to $25 \mathrm{Mc} / \mathrm{s}$. in $30 \mathrm{sec}$., emitting 30 pulses per sec. of $50 \mu s e c$. duration. The peak power transmitted is about $10 \mathrm{~kW}$., from one of two vertical rhombic aerials used for the lower and upper parts of this frequency range (1-4 and 4-25 Mc./sec.). On normal days, soundings are made at about fifteen-minute intervals; but during the Regular World Days and Special World Intervals of the International Geophysical Year, soundings were made every five minutes.

The bulletins of Ionospheric Observations taken during July-October 1958, inclusive, have recently been issued. These are similar in form to those issued for the preceding months of the International Geophysical Year; and contain graphs of the median monthly values of the heights and critical frequencies of the $E, F 1$ and $F 2$ regions, and also curves showing the percentage of the total time during which the critical frequency of the sporadic $E s$ layer exceeded the limiting values of 3,5 and $7 \mathrm{Mc}$./sec. In addition to these graphs, the individual hourly observed values are given for the $F 2, F 1, E$ and $E s$ layers. Additional tables give the maximum usable frequencies for radio transmission over a distance of $3,000 \mathrm{~km}$. by the $F 2$ and $F 1$ layers, and other values relating to the height and critical frequency of the sporadic $E$ region. The symbols used throughout the bulletins conform with the decisions of the Union Radio-Scientifique Internationale/International Geophysical Year sub-com. mittee on Ionospheric Soundings. 